\title{
The Cylindrical Inclusion Gene of Turnip mosaic virus Encodes a Pathogenic Determinant to the Brassica Resistance Gene TuRB01
}

\author{
C. E. Jenner, ${ }^{1}$ F. Sánchez, ${ }^{2}$ S. B. Nettleship, ${ }^{3}$ G. D. Foster, ${ }^{3}$ F. Ponz, ${ }^{2}$ and J. A. Walsh ${ }^{1}$ \\ ${ }^{1}$ Horticulture Research International, Wellesbourne, Warwick, CV35 9EF, U.K.; ${ }^{2}$ Dpto. Mejora Genética y \\ Biotecnología, INIA, Autopista A-6, km 7. 28040 Madrid, Spain; ${ }^{3}$ School of Biological Sciences, University \\ of Bristol, Bristol, BS8 1UG, U.K. \\ Accepted 6 June 2000.
}

\begin{abstract}
The viral component of Turnip mosaic virus (TuMV) determining virulence to the Brassica napus TuRBO1 dominant resistance allele has been identified. Sequence comparisons of an infectious cDNA clone of the UK 1 isolate of TuMV (avirulent on TuRB01) and a spontaneous mutant capable of infecting plants possessing TuRBO1 suggested that a single nucleotide change in the cylindrical inclusion (CI) protein coding region (gene) of the virus was responsible for the altered phenotype. A second spontaneous mutation involved a different change in the $\mathrm{CI}$ gene. The construction of chimeric genomes and subsequent inoculations to plant lines segregating for TuRBO1 confirmed the involvement of the $\mathrm{CI}$ gene in this interaction. Site-directed mutagenesis of the viral coat protein (CP) gene at the ninth nucleotide was carried out to investigate its interaction with TuRBO1. The identity of this nucleotide in the CP gene did not affect the outcome of the viral infection. Both mutations identified in the $C I$ gene caused amino acid changes in the $\mathrm{C}$ terminal third of the protein, outside any of the conserved sequences reported to be associated with helicase or cell-to-cell transport activities. This is the first example of a potyvirus CI gene acting as a determinant for a genotype-specific resistance interaction.
\end{abstract}

Research on plant-virus interactions has contributed significantly to the understanding of genotype-specific disease resistance in plants. The study of infection, virus spread, and disease development in plants has been greatly aided by the recent availability of infectious genomic clones of several virus species. Viral components such as movement proteins, coat proteins (CPs), and replicases are essential for the establishment of infection and, in a few cases, the involvement of such proteins with specific plant resistance responses have been determined. Tobamoviruses have been best studied to date in this context, with all the viral genes implicated in various resistance responses. The $\mathrm{CP}$ is a direct elicitor of resistance in plants with the genes $N^{\prime}, L^{1}, L^{2}$, or $L^{3}$ (Culver and

Corresponding author: Carol Jenner; E-mail: carol.jenner@hri.ac.uk

Sequence data for TuMV UK 1 cDNA contained in $\mathrm{p} 35 \mathrm{Tu}$ has been submitted to the GenBank data base as accession number AF169561.
Dawson 1991; Berzal-Herranz et al. 1995; de la Cruz et al. 1997; Gilardi et al. 1998). The movement protein is an elicitor for resistance genes Tm-2 and Tm-2 $2^{2}$ (e.g., Meshi et al. 1989; Weber and Pfitzner 1998). Similarly, the replicase protein is an elicitor in $N$-mediated resistance (Padgett and Beachy 1993; Erickson et al. 1999), and the replicase gene is implicated in Tm-1 resistance (Meshi et al. 1988). The potexvirus Potato virus $X$ (PVX) has also been well studied, with the CP implicated in $R x 1, R \times 2$, and $N x$ resistances (Santa Cruz and Baulcombe 1993; Bendahmane et al. 1995; Querci et al. 1995), whereas the movement protein is the elicitor in $N b$-mediated resistance (Malcuit et al. 1999).

The family Potyviridae is the largest family of plant viruses (Shukla et al. 1994) and members of this group cause many economically important diseases, but knowledge of the molecular basis of resistance breaking and elicitor identity is less advanced than for tobamoviruses and PVX. Domains of the Soybean mosaic virus HC-Pro and P3 genes are jointly associated with Rsvl resistance breaking (Eggenberger and Hill 1997). However, the VPg gene has so far been most commonly associated with resistance, e.g., with $v a$-mediated resistance for Potato virus $Y$ (PVY) and Tobacco vein mottling virus (Nicolas et al. 1997; Masuta et al. 1999), two other recessive genes acting against Tobacco etch virus (Schaad et al. 1997), and for $s b m-1$ and $s b m-3$ resistances against Pea seedborne mosaic virus (Keller et al. 1998). The VPg gene has also been associated with the ability of Potato virus A to move systemically in Nicandra physaloides (together with the 6K2 gene) (Rajamäki and Valkonenen 1999) and with strainspecific resistance in potato (together with the HC-Pro, $\mathrm{CP}$, or both) (Hämäläinen et al. 2000).

Turnip mosaic virus (TuMV), a member of the family Potyviridae, is the most important virus infecting cruciferous crops and is found worldwide (Shattuck 1992). It has a wide host range, and sources of resistance have been identified in a number of Brassica spp. and other plant species (Shattuck 1992). However, the map positions of only three resistance genes have been published to date: $T u$ in lettuce (Robbins et al. 1994), and TuRBO1 and TuRBO2 in B. napus (Walsh et al. 1999). Further resistance sources are being characterized and the genes involved are being mapped (Rusholme et al. 1999). In this article, we report the use of an infectious cDNA clone of TuMV, p35Tunos (Sánchez et al. 1998), to examine viral 
components involved in TuRBO1 resistance, and demonstrate the first example of a potyvirus cylindrical inclusion (CI) gene as a determinant of virulence to a plant resistance gene.

\section{RESULTS}

\section{Isolation of mutants.}

The infectious cDNA clone p35Tunos (Sánchez et al. 1998) was constructed from the isolate TuMV UK 1, a typical pathotype 1 isolate that systemically infects $B$. napus differential lines S1 and S6 but is incapable of infecting lines R4 and 165 (Jenner and Walsh 1996). On inoculation to B. napus plants, the virus produced from p35Tunos DNA (denoted as v35Tunos) behaved like UK 1 except that, occasionally, a single R4 plant developed two or three small necrotic spots after several weeks. Virus was isolated from two such plants, from occasions separated by several months, and named v35TunosM1 and v35TunosM2. The isolates UK $1 \mathrm{M}$ and UK 1M2 were isolated from B. napus cv. Westar (Jenner and Walsh 1996) and line R4 plants (J. A. Walsh, unpublished data) respectively, following inoculation with UK 1 . All of these mutants consistently infected B. napus line R4 and the doubled-haploid B. napus line N-o-1 (Sharpe et al. 1995) possessing TuRB01 (Walsh et al. 1999). Symptoms consisted of striking local necrotic lesions with systemic virus spread giving rise to smaller necrotic lesions on leaves, stems, and petioles. The altered phenotype was produced even after repeated subcultures of the virus in a plant host not possessing TuRBO1 (B. juncea cv. Tendergreen).

\section{Analysis of sequences of mutants.}

The sequence of TuMV UK 1 cDNA contained in p35Tu (Sánchez et al. 1998) has been submitted to GenBank as accession number AF169561. The plasmid p35Tunos was generated from p35Tu (Sánchez et al. 1998). It has a single nucleotide difference from $\mathrm{p} 35 \mathrm{Tu}$ in the CP gene (at base 9195, where $\mathrm{C}$ replaces $\mathrm{T}$ ). The cDNA sequence of the $\mathrm{CP}$ of virus derived from p35Tunos (v35Tunos) matched p35Tunos and UK 1.

The $5^{\prime}$ end of v35Tunos and v35TunosM1 from Tendergreen mustard or line R4 plants consisted of four to six A residues, although six residues were used in the construction of p35Tunos (Sánchez et al. 1998). This variation in the TuMV genome has been reported previously (Nicolas and Laliberté 1992). We have, therefore, numbered the nucleotides of mutations according to recent recommendations in which base +1 is the A of the start codon of the open reading frame (ORF) (Antonarakis and the Nomenclature Working Group 1998).

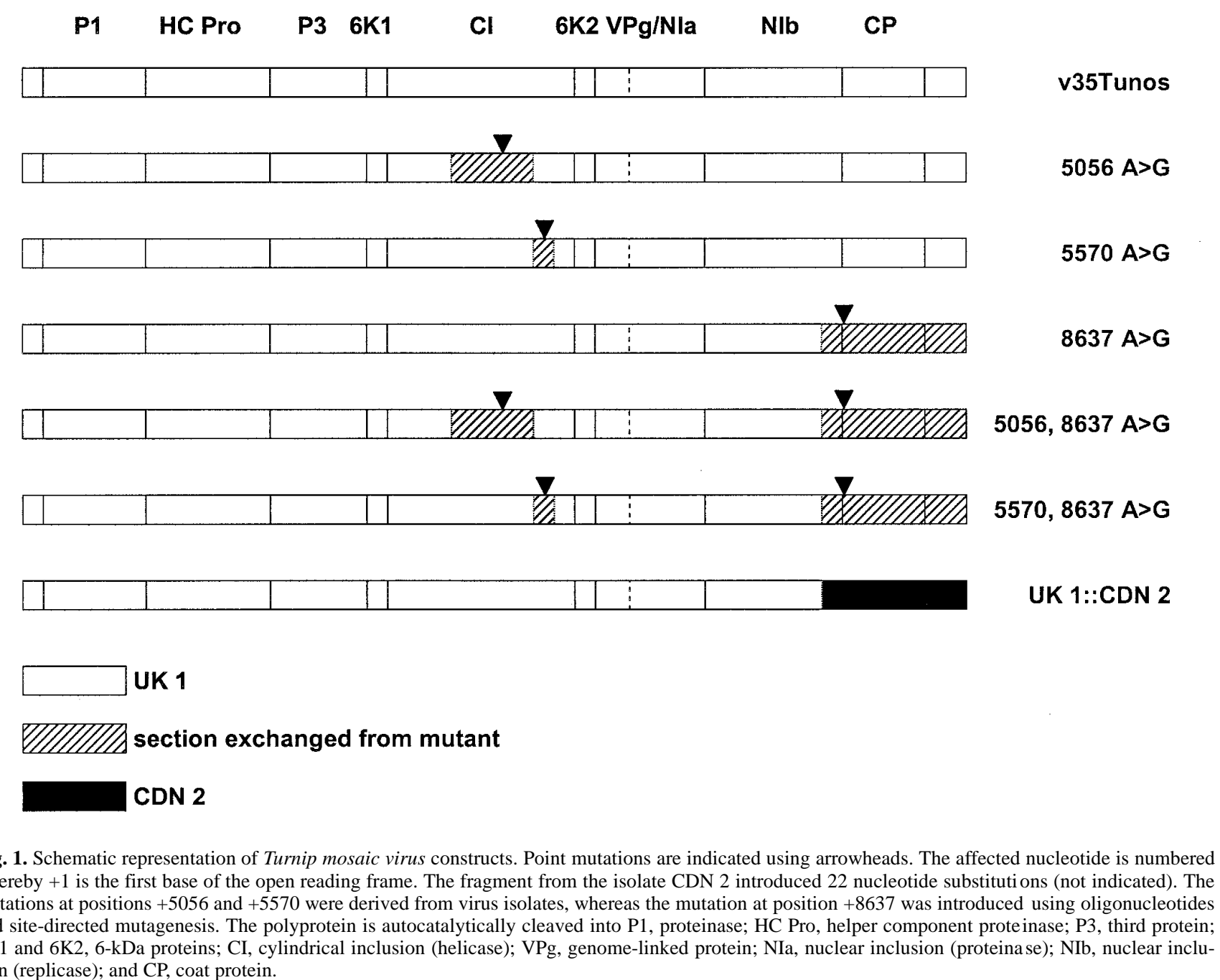
6K1 and 6K2, 6-kDa proteins; CI, cylindrical inclusion (helicase); VPg, genome-linked protein; NIa, nuclear inclusion (proteina se); NIb, nuclear inclusion (replicase); and CP, coat protein. 
The complete sequence of v35TunosM1 was determined from virus present in systemically infected $B$. napus line R4 plants. The sequences of p35Tunos and the mutant v35TunosM1 differed by a single nucleotide substitution at position +5056 : $A$ in the former, $G$ in the latter. The mutation affected residue 1686 of the polyprotein, changing a predicted asparagine to aspartate in the CI protein.

The sequence of the CI region was determined similarly for the mutants UK 1M, UK 1M2, and v35TunosM2. The isolate UK $1 \mathrm{M}$ differed from $\mathrm{p} 35$ Tunos at position +5570 , where the mutant contained a $\mathrm{G}$ instead of $\mathrm{A}$. This affected residue 1857 of the polyprotein, changing the predicted amino acid from histidine to arginine. Both UK 1M2 and v35TunosM2 contained the same mutation as v35TunosM1 at position +5056 , but UK 1M2 differed additionally at position +4685 (changing from a $\mathrm{G}$ to an $\mathrm{A}$ and altering the predicted serine residue at position 1562 to asparagine).

\section{Behavior of recombinant viruses containing point mutations in the CI gene on B. napus lines possessing TuRB01.}

Recombinant viruses v35Tunos 5056A $>\mathrm{G}$ and v35Tunos $5570 \mathrm{~A}>\mathrm{G}$ were derived from the plasmids p35Tunos 5056A $>\mathrm{G}$ and p35Tunos 5570A $>\mathrm{G}$ (Fig. 1). Each was tested for its ability to infect $B$. napus lines S1, S6, 165, R4, N-o-1, and N-o-9 (Table 1). The viruses containing the point mutations in the CI gene infected the same lines as the parental mutants, breaking the resistance in lines $\mathrm{N}-\mathrm{o}-1$ and $\mathrm{R} 4$ and producing symptoms and virus content (as measured by enzyme-linked immunosorbent assay [ELISA]) (data not shown) indistinguishable from the original mutants. Symptoms induced by v35Tunos $5570 \mathrm{~A}>\mathrm{G}$ (and $\mathrm{UK} 1 \mathrm{M}$ ) were more severe than those induced by v35Tunos $5056 \mathrm{~A}>\mathrm{G}$ (and v35TunosM1). Both mutants induced symptoms of greater severity on line R4 than on line $\mathrm{N}-\mathrm{o}-1$. The sequences of the exchanged sections of genome were confirmed in virus derived from both constructs following reverse transcription-polymerase chain reaction (RT-PCR) on infected N-o-1 plants. The sequence around the position of the other alternative mutation was also confirmed. None of the mutants or chimeras was able to overcome the resistance present in line 165

Line N-o-1 possesses the resistance gene TuRBO1; therefore, the recombinant viruses were also tested on 10 doubledhaploid lines, derived from a cross of N-o-1 with N-o-9 (Table
2), that are known to be segregating for the presence of TuRBO1 (Walsh et al. 1999). Recombinant viruses containing the mutations infected the lines lacking TuRBO1 in the same manner as the wild-type infectious clone, and overcame the resistance in the lines possessing TuRBO1 with the same symptoms seen on line N-o-1 (Fig. 2). This confirmed that either single nucleotide change was sufficient to enable the virus to overcome TuRBO1 resistance.

\section{Experiments on the CP sequence of TuMV and TuRBO1 resistance.}

Four additional viral constructs were produced to examine the potential effect of the $\mathrm{CP}$ sequence on resistance breaking (Fig. 1). In the first, the section of p35Tunos encompassing the $\mathrm{CP}$ coding region and $3^{\prime}$ untranslated region of UK 1 was replaced by cDNA of this same region derived from TuMV CDN 2. The isolate CDN 2 is a typical pathotype 3 isolate (Jenner and Walsh 1996) and produced similar symptoms on lines $\mathrm{N}-\mathrm{o}-1$ and $\mathrm{R} 4$ to the UK 1 mutants. The exchanged section introduced 23 nucleotide substitutions, altering six amino acids of the CP (polyprotein positions 2915 Lys $>$ Gln, 2919 Asp>Asn, 2926 Lys>Glu, 2958 Lys>Gln, 3057 Met>Ile, and $3162 \mathrm{Gln}>$ Lys). The recombinant virus infected the same lines as UK 1, and did not infect lines N-o-1 or R4 (Table 1). Sequencing of the $\mathrm{CP}$ section confirmed the identity of the virus present in infected leaves. The presence of CDN $2 \mathrm{CP}$ sequence and protein was not sufficient to enable v35Tunos to overcome TURBO1 resistance, demonstrating that the virulence determinant for TuRBO1 lies outside this region of the viral genome.

Previous work (Lehmann et al. 1997) hypothesized a correlation between TuRBO1 resistance breaking and the nucleotide in the CP region of the ORF at position $+8637(\mathrm{G}>\mathrm{A}$ for virulent isolates). p35Tunos broke this correlation because it had an $\mathrm{A}$ at this position and virus derived from it could not infect lines possessing TuRB01. The CDN 2 sequence introduced above was also A at this position. Therefore, the plasmid p35Tunos was altered to introduce a $\mathrm{G}$ at position +8637 . This base change was also introduced into the two other constructs that contained point mutations in the CI region (Fig. 1). Virus derived from the three $8637 \mathrm{~A}>\mathrm{G}$ constructs infected the same $B$. napus lines to the same degree as the three $+8637 \mathrm{~A}$ constructs (Table 1). The sequence around positions +5056 , +5570 , and +8637 of all three viruses was confirmed from

Table 1. Phenotypes of the interactions between Turnip mosaic virus isolates, mutants, and virus derived from cDNA constructs and Brassica napus lines

\begin{tabular}{|c|c|c|c|c|c|c|}
\hline \multirow[b]{2}{*}{ Virus isolate } & \multicolumn{6}{|c|}{ B. napus line } \\
\hline & N-o-1 ${ }^{\mathbf{a}}$ & R4 & 165 & N-o-9 ${ }^{\mathbf{a}}$ & S1 & S6 \\
\hline UK 1 & $0^{\mathrm{b}}$ & 0 & 0 & $+^{c}$ & + & + \\
\hline UK $1 \mathrm{M}$ & $+_{N}^{d}$ & $t_{N}$ & 0 & + & + & + \\
\hline v35TunosM1 & $t_{N}$ & $t_{N}$ & 0 & + & + & + \\
\hline CDN 2 & $t_{N}$ & $t_{N}$ & 0 & + & + & + \\
\hline v35Tunos $5056 \mathrm{~A}>\mathrm{G}$ & $t_{N}$ & $+_{\mathrm{N}}$ & 0 & + & + & + \\
\hline v35Tunos 5570A $>\mathrm{G}$ & $t_{N}$ & $t_{\mathrm{N}}$ & 0 & + & + & + \\
\hline UK $1:: C D N ~ 2 ~ C P+3 '$ UTR & 0 & 0 & 0 & + & + & + \\
\hline v35Tunos $8637 \mathrm{~A}>\mathrm{G}$ & 0 & 0 & 0 & + & + & + \\
\hline v35Tunos 5056+8637A $>$ G & $t_{N}$ & $+_{N}$ & 0 & + & + & + \\
\hline v35Tunos $5570+8637 \mathrm{~A}>\mathrm{G}$ & $t_{N}$ & $t_{\mathrm{N}}$ & 0 & + & + & + \\
\hline
\end{tabular}

a Line N-o-1 possesses the resistance gene TuRBO1 and line N-o-9 lacks TuRBO1.

b $0=$ No symptoms in any plants, and no virus was detected by enzyme-linked immunosorbent assay (ELISA).

${ }^{c}+=$ All plants displayed systemic mosaic, and virus was detected by ELISA.

${ }^{\mathrm{d}}+_{\mathrm{N}}=$ All plants displayed systemic necrosis, and virus was detected by ELISA. 
infected N-o-1 leaves (constructs containing CI mutations) or from infected S6 leaves (v35Tunos 8637A $>$ G, which did not infect line N-o-1). These experiments showed that the identity of the base at position +8637 was not the determining factor in the ability to overcome TuRBO1 resistance.

The correlation of resistance breaking with position $+8637 \mathrm{~A}$ that was noted by Lehmann et al. (1997) was based upon the $\mathrm{CP}$ sequences of a small number of isolates (three isolates had a G, including UK 1, and four isolates had an A, including UK $1 \mathrm{M})$. The CP sections of seven further samples of UK 1 have now been sequenced, ranging from freeze-dried material from 1993 to virus in current culture. In all cases, the sequence matched that of p35Tunos, in which the nucleotide at position +8637 was A.

\section{DISCUSSION}

The identification of the TuMV CI coding region (gene) as a virulence determinant for the resistance gene TuRBO1 has been achieved through the characterization of v35TunosM1, a mutant derived from the infectious clone of TuMV UK 1. This has been confirmed by the discovery of a second mutation in the same gene (of TuMV UK 1M). The genotype specificity of this interaction was confirmed by inoculation of chimeric clones to plant lines segregating for TuRB01. This finding is novel for potyviruses, in that the CI gene has not previously been implicated in any genotype-specific resistance response.

The ability of virus containing an altered base in the $\mathrm{CP}$ gene at position $+8637(A>G)$ and either of the two CI mutations to infect plants possessing TuRB01 showed that the CP sequence is not involved in resistance breaking. This, along with the identification of a number of virus isolates unable to break the resistance (P. J. Hunter and S. B. Nettleship, unpublished data) (and all isolates of UK 1 sequenced) with A at position +8637 , has demonstrated that the hypothesis about a possible involvement of the $\mathrm{CP}$ sequence at this position in the interaction with TuRBO1 proposed by Lehmann et al. (1997) is not valid. It appears that the original finding of base $+8637 \mathrm{G}$ in UK 1 was either an error generated during PCR prior to cloning, or a subpopulation that has since been replaced by the A population.

The CI protein of potyviruses is a helicase (Laín et al. 1990) of the superfamily SF2 type (Kadaré and Haenni 1997) and has a role in viral cell-to-cell movement (Rodríguez-Cerezo et al. 1997; Carrington et al. 1998; Roberts et al. 1998). There are a few examples of the association of other viral movement proteins with resistance breaking. These include the movement proteins of Tomato bushy stunt virus (Chu et al. 1999), PVX (Malcuit et al. 1999), and tobamoviruses (Meshi et al. 1989; Weber and Pfitzner 1998). Infection of lines lacking TuRBO1 by the mutants or the chimeras appeared to be identical to infections by the wild-type virus, in that clear systemic symptoms were seen and the virus content as measured by ELISA was indistinguishable from that of wild-type virus. This suggested that the mutations were not deleterious to the ability to infect and spread through plants not possessing TuRBO1. The altered phenotype was seen even after repeated subcultures in a plant host not possessing TuRB01; therefore, the mutations appeared to be stable. Both mutations (at positions +5056 and +5570 ) were outside the seven amino acid motifs associated with helicase action (Kadaré and Haenni 1997) and the sections of sequence thought to have a role in viral movement (Carrington et al. 1998). The effect of the mutations on the tertiary and quaternary structure of the native protein and the structural position of the mutations relative to the above functional regions are not known. The Chou and Fasman algorithm (Protean program of DNASTAR, Chou 1990) predicted that the mutation at position +5056 would disrupt a very small region of $\beta$-sheet secondary structure. The CI protein accumulates around plasmodesmata in the early stages of infection before releasing into the cytoplasm as characteristic inclusion bodies that slowly degrade (Roberts et al. 1998). Electron microscopy revealed no obvious structural alteration in inclusion bodies produced by v35TunosM1 or v35Tunos 5570A $>\mathrm{G}$ (data not shown).

It is not known whether the mutation in v35TunosM1 arose in the original Chenopodium quinoa plant inoculated with plasmid DNA, in the mustard plant inoculated subsequently, or in the B. napus $\mathrm{R} 4$ plant under the selection pressure of a resistance gene. The R4 line possesses a single dominant allele for resistance to UK 1 (Walsh 1989) that has the same specificity to different TuMV isolates as TuRBO1 (Walsh et al. 1999), suggesting that it possesses TuRBO1. This is also supported by the results described here, in that the single nucleotide changes in the TuMV genome gave the same phenotypic changes on line R4 plants as on plants possessing TuRBO1. The virus mutation could only have arisen in the R4 plant if at least one round of viral replication had occurred before the resistance mechanism was triggered. Such a level of multiplication may be too low for our methods to detect.

CI gene involvement in specific interactions is not limited to TuRB01 resistance. There is specificity in the association of the CI protein with the CP (Langenberg 1993). The CI protein may also possibly trigger a range of host responses associated with infection (Roberts et al. 1998). The mechanism of TuRBO1 resistance is not yet understood, particularly because it lacks an obvious hypersensitive reaction (HR). Some movement proteins in other virus-host interactions are direct elicitors of resistance (e.g., the 25-kDa movement protein of PVX is the elicitor of $N b$-mediated resistance [Malcuit et al. 1999]

Table 2. Phenotypes of the interactions between Turnip mosaic virus isolates derived from cDNA constructs containing point mutations in the cylindrical inclusion gene and doubled-haploid Brassica napus lines derived from a cross of N-o- $1 \times \mathrm{N}-\mathrm{o}-9$ used to map TuRBO1

\begin{tabular}{|c|c|c|c|c|}
\hline \multirow[b]{2}{*}{ Plant line } & \multirow[b]{2}{*}{$\begin{array}{c}\text { Presence } \\
\text { of } T u R B 01\end{array}$} & \multicolumn{3}{|c|}{ Viral isolate/construct } \\
\hline & & v35Tunos & $\begin{array}{l}\text { v35Tunos } \\
5056 \text { A }>\text { G }\end{array}$ & $\begin{array}{l}\text { v35Tunos } \\
\text { 5570A }>\text { G }\end{array}$ \\
\hline N-72-8-1-48 & Yes & $0^{\mathrm{a}}$ & $+_{N}^{b}$ & $+_{N}$ \\
\hline $\mathrm{N}-72-8-2-69$ & Yes & 0 & $+_{N}$ & $+_{N}$ \\
\hline N-72-8-2-126 & Yes & 0 & $++_{N}$ & $+_{N}$ \\
\hline $\mathrm{N}-72-8-2-152$ & Yes & 0 & $\begin{array}{r}{ }_{N} \\
+_{N}\end{array}$ & $+_{N}$ \\
\hline N-72-8-3-241 & Yes & 0 & $+_{N}$ & $+_{N}$ \\
\hline N-72-8-1-12 & No & $+^{\mathrm{c}}$ & + & + \\
\hline N-72-8-1-54 & No & + & + & + \\
\hline N-72-8-1-178 & No & + & + & + \\
\hline N-72-8-2-77 & No & + & + & + \\
\hline N-72-8-2-137 & No & + & + & + \\
\hline
\end{tabular}

${ }^{\mathrm{a}} 0=$ No symptoms in any plants, and no virus was detected by enzymelinked immunosorbent assay (ELISA).

${ }^{\mathrm{b}}+_{\mathrm{N}}=$ All plants displayed systemic necrosis, and virus was detected by ELISA.

${ }^{c}+=$ All plants displayed systemic mosaic, and virus was detected by ELISA. 
and the $30-\mathrm{kDa}$ movement protein of Tomato mosaic virus elicits $T m 2^{2}$ resistance [Weber and Pfitzner 1998]). However, our data are not sufficient to infer whether the viral RNA or the CI protein itself is the elicitor or acts via intermediates. It is probable that the overall protein structure rather than individual amino acid residues is important in the interaction, because two distinct amino acid alterations altered the phenotype observed. It is possible that the mutations act as a suppressor of the resistance mechanism or that the CI protein is the elicitor and the mutations alter its structure. The production of systemic necrotic lesions by the virulent mutants in lines possessing TuRB01, rather than the chlorotic mosaic seen in lines lacking TuRBO1, might suggest that other (later and lesseffective) resistance mechanisms are being triggered. If this is the case, TuRBO1 must be epistatic to host genes involved in the limited cell death (necrosis) observed. It is interesting to note that the non-HR resistance conferred by $R x$ (Kavanagh et al. 1992) has also been reported to be epistatic to a HR (Bendahmane et al. 1999). It is hoped that wild-type TuMV isolates (pathotype 4) (Jenner and Walsh 1996) and the identi-

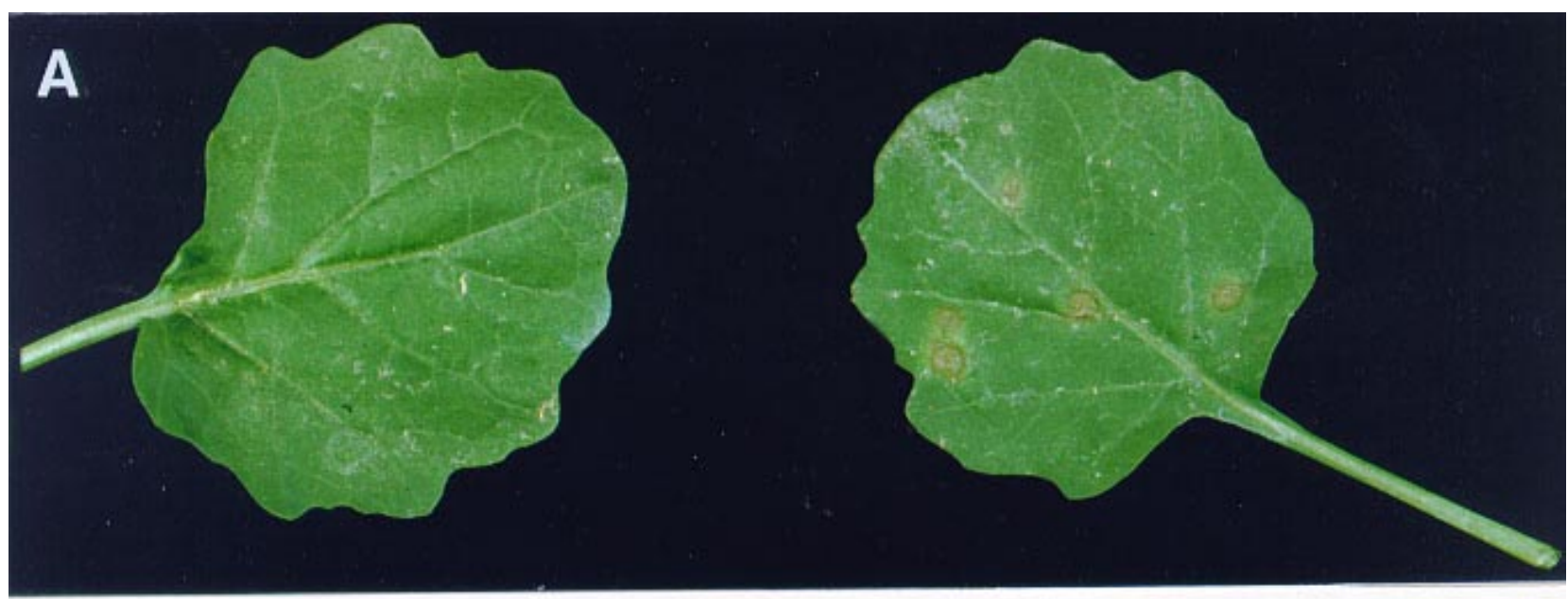

B

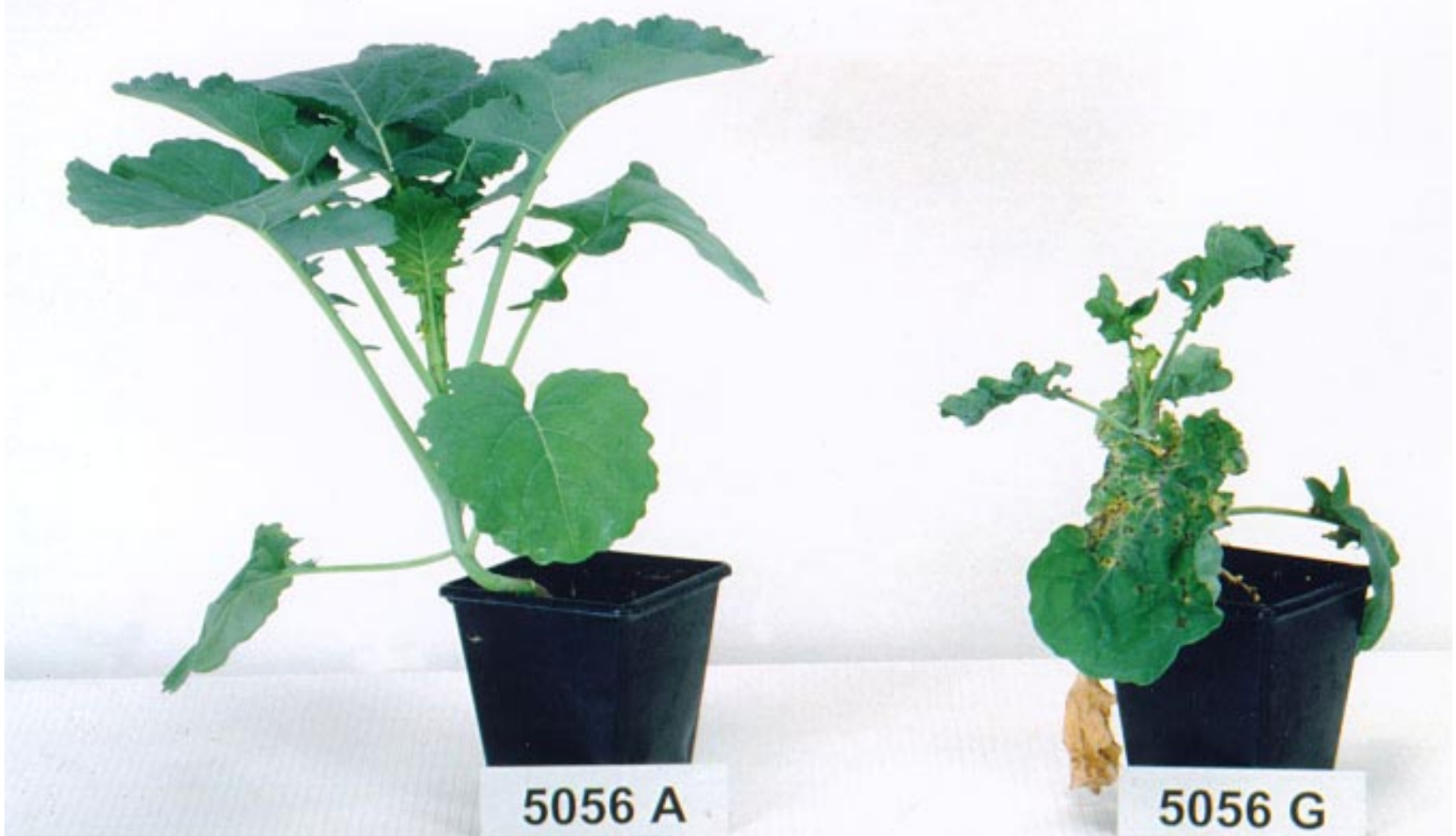

Fig. 2. Brassica napus plants (doubled-haploid line N-72-8-2-152 possessing TuRB01) following inoculation with (on left) v35Tunos and (on right) v35Tunos 5056A>G. A, Leaves 7 days after inoculation. B, Plants 25 days after inoculation. 
fication of further mutants able to overcome TuRBOI without inducing necrosis, together with the use of transient expression assays, will enable us to gain a better understanding of the mechanism of TuRBO1-mediated resistance.

\section{MATERIALS AND METHODS}

\section{Plants and virus infections.}

B. napus lines S1, S6, 165, R4 (Jenner and Walsh 1996), No-1, and N-o-9 (Sharpe et al. 1995) have been described previously. The 10 doubled-haploid lines (Table 2) were derived by microspore culture from an $\mathrm{F}_{1}$ plant from N-o- $1 \times \mathrm{N}-\mathrm{O}-9$ (Sharpe et al. 1995) and the presence of TuRBOl determined previously (Walsh et al. 1999). Plants were grown in an insectproof glasshouse, and viruses were transmitted by mechanical inoculation as described previously (Jenner and Walsh 1996). cDNA clones of TuMV were purified using plasmid midi preparations (Qiagen, Crawley, U.K.). Five micrograms of plasmid ( $\left.1 \mathrm{mg} \mathrm{ml}^{-1}\right)$ was sufficient to infect $C$. quinoa and $B$. juncea (mustard) cv. Tendergreen. About half of the Tendergreen mustard plants and almost all of the $C$. quinoa plants became infected following inoculation with plasmid preparations. Interactions between virus isolates and plants were determined essentially as described by Jenner and Walsh (1996) using 10 plants per line, or four plants where the plants were doubled-haploid lines. Symptoms were assessed weekly for 4 weeks, after which the presence of TuMV was assessed by plate-trapped antigen ELISA using the monoclonal antibody EMA 67 (Jenner et al. 1999).

\section{RT-PCR.}

Oligonucleotide primers were based on the sequence of p35Tunos and designed using PrimerSelect (DNASTAR Inc., Madison, WI, U.S.A.) to produce overlapping products of approximately $1 \mathrm{~kb}$. Leaf samples were ground in sample buffer (0.5 M Tris, pH 8.3;0.15 M NaCl; $0.05 \%$ Tween $20 ; 2 \%$ polyvinylpyrrolidone; and $1 \%$ polyethylene glycol 6000) and diluted to $2 \mathrm{mg} \mathrm{ml}^{-1}$. cDNA was prepared using SuperscriptII reverse transcriptase (Life Technologies, Paisley, U.K.) according to manufacturer's recommendations and with added ribonuclease inhibitor ( $2 \mathrm{U}$ per reaction), using $2 \mu \mathrm{l}$ of sap per $20-\mu l$ reaction. The cDNA was amplified by PCR using $2.5 \mathrm{U}$ of Taq DNA polymerase (Life Technologies) and 5 pmol of each oligonucleotide primer, in $20 \mathrm{mM}$ Tris $\mathrm{pH} 8.3,50 \mathrm{mM}$ $\mathrm{KCl}, 4 \mathrm{mM}$ dithiothreitol, $0.2 \mathrm{mM} \mathrm{dNTP}$, and $1.5 \mathrm{mM} \mathrm{MgCl}_{2}$. PCR was performed for 35 cycles at temperatures appropriate for the primer combinations in use. DNA products were separated on $1 \%$ agarose gels and were isolated from the gel using QIAquick gel extraction kits (Qiagen).

\section{DNA sequencing.}

The sequence of TuMV UK 1 cDNA contained in p35Tu (Sánchez et al. 1998) was determined from plasmid DNA at least three times per strand. The sequences of the mutant viruses were determined in both directions from RT-PCR products from virus present in systemically infected B. napus $\mathrm{R} 4$ plants. The complete sequence of v35TunosM1 was determined, but only the section encompassing the CI gene was determined for the other mutants. Sequencing reactions were prepared using the Big Dye Terminator cycle sequencing ready reaction mix (PE-Applied Biosystems, Foster City, CA,
U.S.A.) and run through $4.25 \%$ acrylamide gels on ABI 373A (Sequiserve, Vaterstetten, Germany) and ABI 377 Automated Sequencers. The sequences were assembled using SeqMan (DNASTAR). Sections of the mutants differing from p35Tunos were determined from three independent RT-PCR reactions. The sequence of p35Tunos in planta (i.e., v35Tunos) for these sections was also checked. The $5^{\prime}$ nucleotides were determined using a 5' RACE kit (Life Technologies); the 3' nucleotides were obtained using 5'-GCGTCGACTAGTACTCGAGTTTTTTTTTTT-3' (P3S) as the reverse primer.

\section{Construction of recombinant viruses.}

A 1.2-kb RT-PCR product of v35TunosM1 encompassing the mutation at position +5056 was obtained from infected R4 leaves using the primers 5'-TGAACGCACAGGGTAT-3' and 5'-ATATTCCATCGGTTTTTGTA-3'. The mutation at position +5570 was similarly obtained in a $1.3-\mathrm{kb}$ product from UK $1 \mathrm{M}$ using the primers $5^{\prime}$-GGTGGGACGTCCTTTGGTAAC-3' and 5'-CAGGTTTTGGTCGGCTTTCA-3'. The CP section of CDN 2 was obtained from infected TGM leaves using 5'-CTGGAACCTGAGCGAATAGTATCG-3' and P3S. Each product was cloned into pMOSBlue (Amersham, Little Chalfont, U.K.) according to manufacturer's recommendations and the sequences of the clones were checked. The mutation $5056 \mathrm{~A}>\mathrm{G}$ was introduced into p35Tunos in a $1.0-\mathrm{kb}$ MunI-BstEII fragment, $5570 \mathrm{~A}>\mathrm{G}$ in a $0.2-\mathrm{kb}$ BstEII-Sst $\mathrm{I}$ fragment, and the CDN 2 CP section in a 1.3-kb MluI-SalI fragment.

The nucleotide at position +8637 (CP nucleotide 9) was changed from A to $\mathrm{G}$ using subclones of p35Tunos. A 3.8-kb PstI-SalI fragment was cloned into pMOSBlue, and then a 14bp BspMI fragment encompassing position +8637 was removed and replaced with a pair of annealed complementary $5^{\prime}$-phosphorylated oligonucleotides (5'-ATCACCAGGCAGGTGAGA-3' and 5'-AGCGTCTCACCTGCCTGG-3'). Similarly, a 1.6-kb MluI-ApaI fragment was cloned into the plasmid pSL1180 (Amersham Pharmacia Biotech, St. Albans, U.K.). Mutagenesis of this clone was performed using the mutagenic oligonucleotide 5'-GCAGGTGAGACGCTTGAT$3^{\prime}$ in the GeneEditor in vitro Site-Directed Mutagenesis System (Promega Corporation, Southampton, U.K.). Mutagenized fragments (1.3-kb MluI-SalI or 1.6-kb MluI-ApaI, respectively) were replaced into p35Tunos, p35Tunos 5056A $>\mathrm{G}$, and p35Tunos 5570A $>$ G.

Recombinant clones were identified by standard methods prior to inoculation onto both $C$. quinoa and Tendergreen mustard plants for use as the source of inoculum for experiments using B. napus. The presence of the mutations was confirmed by sequencing the plasmids and RT-PCR products derived from virus present in infected $B$. napus line N-o-1 leaves (or line S6 where line N-o-1 was not infected) using the above primers.

\section{ACKNOWLEDGMENTS}

This work was funded by the BBSRC core strategic grant to Horticulture Research International (HRI) and a BBSRC Ph.D. studentship to S. B. N. The collaboration between HRI and INIA was assisted by a grant from the Acciones Integradas program from the British Council and the Ministerio de Educación y Cultura, Spain. We thank C. Clay for electron microscopy; J. Beynon for help with sequence determinations; D. Lydiate, A. Sharpe, and I. Parkin for the B. napus lines used for mapping TuRB01; and Advanta and CPB-Twyford for allowing us to use the $B$. napus population in which TuRBO1 had been mapped. The recombi- 
nant constructs were prepared and held in the U.K. under MAFF 1icences PHL 5C/2698, 5D/3081, and 5F/3418.

\section{LITERATURE CITED}

Antonarakis, S. E., and the Nomenclature Working Group, 1998. Recommendations for a nomenclature for human gene mutations. Hum. Mutat. 11:1-3.

Bendahmane, A., Kanyuka, K., and Baulcombe, D. C. 1999. The $R x$ gene from potato controls separate virus resistance and cell death responses. Plant Cell 11:781-791.

Bendahmane, A., Köhm, B., Dedi, C., and Baulcombe, D. C. 1995. The coat protein of potato virus $\mathrm{X}$ is a strain-specific elicitor of $R x 1$ mediated resistance in potato. Plant J. 8:933-941.

Berzal-Herranz, A., de la Cruz, A., Tenllado, F., Díaz-Ruíz, J. R., López, L., Sanz, A. I., Vaquero, C., Serra, M. T., and García-Luque, I. 1995. The Capsicum $\mathrm{L}^{3}$ gene-mediated resistance against the tobamoviruses is elicited by the coat protein. Virology 209:498-505.

Carrington, J. C., Jensen, P. E., and Schaad, M. C. 1998. Genetic evidence for an essential role for potyvirus CI protein in cell-to-cell movement. Plant J. 14:393-400.

Chou, P. Y. 1990. Prediction of protein structural classes from amino acid composition. Pages 549-586 in: Prediction of Protein Structure and the Principles of Protein Conformation. Plenum Press, New York, U.S.A.

Chu, M., Park, J.-W., and Scholthof, H. B. 1999. Separate regions on the tomato bushy stunt virus p22 protein mediate cell-to-cell movement versus elicitation of effective resistance responses. Mol. Plant-Microbe Interact. 4:285-292.

Culver, J. N., and Dawson, W. O. 1991. Tobacco mosaic virus elicitor coat protein genes produce a hypersensitive phenotype in transgenic Nicotiana sylvestris plants. Mol. Plant-Microbe Interact. 4:458-463.

de la Cruz, A., López, L., Tenllado, F., Díaz-Ruíz, J. R., Sanz, A. I., Vaquero, C., Serra, M. T., and García-Luque, I. 1997. The coat protein is required for the elicitation of the Capsicum $\mathrm{L}^{2}$ gene-mediated resistance against the tobamoviruses. Mol. Plant-Microbe Interact. 10:107-113.

Eggenberger, A. L., and Hill, J. H. 1997. Analysis of resistance-breaking determinants of soybean mosaic virus. (Abstr.) Phytopathology 87(suppl.):S27.

Erickson, F. L., Holzberg, S., Calderon-Urrea, A., Handley, V., Axtell, M., Corr, C., and Baker, B. 1999. The helicase domain of the TMV replicase proteins induces the $\mathrm{N}$-mediated defence response in tobacco. Plant J. 18:67-75.

Gilardi, P., García-Luque, I., and Serra, M. T. 1998. Pepper mild mottle virus coat protein alone can elicit the Capsicum spp. $L^{3}$ genemediated resistance. Mol. Plant-Microbe Interact. 11:1253-1257.

Hämäläinen, J. H., Kekarainen, T., Gebhardt, C., Watanabe, K. N., and Valkonen, J. P. T. 2000. Recessive and dominant genes interfere with the vascular transport of potato virus A in diploid potatoes. Mol. Plant-Microbe Interact. 13:402-412.

Jenner, C. E., Keane, G. J., Jones, J. E., and Walsh, J. A. 1999. Serotypic variation in turnip mosaic virus. Plant Pathol. 48:101-108.

Jenner, C. E., and Walsh, J. A. 1996. Pathotypic variation in turnip mosaic virus with special reference to European isolates. Plant Pathol. 45:848-856.

Kadaré, G., and Haenni, A. L. 1997. Virus-encoded RNA helicases. J. Virol. 71:2583-2590.

Kavanagh, T., Goulden, M., Santa Cruz, S., Chapman, S., Barker, I., and Baulcombe, D. 1992. Molecular analysis of a resistance-breaking strain of potato virus X. Virology 189:609-617.

Keller, K. E., Johansen, I. E., Martin, R. R., and Hampton, R. O. 1998. Potyvirus genome-linked protein (VPg) determines pea seed-borne mosaic virus pathotype-specific virulence in Pisum sativum. Mol. Plant-Microbe Interact. 11:124-130.

Laín, S., Riechmann, J. L., and García, J. A. 1990. RNA helicase-A novel activity associated with a protein encoded by a positive strand RNA virus. Nucleic Acids Res. 18:7003-7006.

Langenberg, W. G. 1993. Structural proteins of three viruses in the Potyviridae adhere only to their homologous cylindrical inclusions in mixed infections. J. Struct. Biol. 110:188-195.

Lehmann, P., Petrzik, K., Jenner, C., Greenland, A., Špak, J., Kozubek, E., and Walsh, J. A. 1997. Nucleotide and amino acid variation in the coat protein coding region of turnip mosaic virus isolates and possible involvement in the interaction with the brassica resistance gene
TuRB01. Physiol. Mol. Plant Pathol. 51:195-208.

Malcuit, I., Marano, M. R., Kavanagh, T. A., de Jong, W., Forsyth, A., and Baulcombe, D. C. 1999. The 25-kDa movement protein of PVX elicits $\mathrm{Nb}$-mediated hypersensitive cell death in potato. Mol. PlantMicrobe Interact. 12:536-543.

Masuta, C., Nishimura, M., Morishita, H., and Hataya, T. 1999. A single amino acid change in viral genome-associated protein of potato virus Y correlates with resistance breaking in 'Virgin A mutant' tobacco. Phytopathology 89:118-123.

Meshi, T., Motoyoshi, F., Adachi, A., Watanabe, Y., Takamatsu, N., and Okada, Y. 1988. Two concomitant base substitutions in the putative replicase genes of tobacco mosaic virus confer the ability to overcome the effects of a tomato resistance gene, Tm-1. EMBO J. 7:1575-1581.

Meshi, T., Motoyoshi, F., Maeda, T., Yoshiwoka, S., Watanabe, H., and Okada, Y. 1989. Mutations in the tobacco mosaic virus 30-kDa protein gene overcome Tm-2 resistance in tomato. Plant Cell 1:515-522.

Nicolas, O., Dunnington, S. W., Gotow, L. F., Pirone, T. P., and Hellmann, G. M. 1997. Variations in the VPg protein allow a potyvirus to overcome $v a$ gene resistance in tobacco. Virology 237:452-459.

Nicolas, O., and Laliberté, J. F. 1992. The complete nucleotide sequence of turnip mosaic potyvirus RNA. J. Gen. Virol. 73:2785-2793.

Padgett, H. S., and Beachy, R. N. 1993. Analysis of a tobacco mosaic virus strain capable of overcoming $N$ gene-mediated resistance. Plant Cell 5:577-586.

Querci, M., Baulcombe, D. C., Goldbach, R. W., and Salazar, L. F. 1995. Analysis of the resistance-breaking determinants of potato virus $\mathrm{X}$ (PVX) strain HB on different potato genotypes expressing extreme resistance to PVX. Phytopathology 85:1003-1010.

Rajamäki, M.-L., and Valkonen, J. P. T. 1999. The $6 \mathrm{~K} 2$ protein and the $\mathrm{VPg}$ of potato virus A are determinants of systemic infection in $\mathrm{Ni}$ candra physaloides. Mol. Plant-Microbe Interact. 12:1074-1081.

Robbins, M. A., Witsenboer, H., Michelmore, R. W., Laliberté, J. F., and Fortin, M. G. 1994. Genetic mapping of turnip mosaic virus resistance in Lactuca sativa. Theor. Appl. Genet. 89:583-589.

Roberts, I. M., Wang, D., Findlay, K., and Maule, A. J. 1998. Ultrastructural and temporal observations of the potyvirus cylindrical inclusions (CIs) show that the CI protein acts transiently in aiding virus movement. Virology 245:173-181.

Rodríguez-Cerezo, E., Findlay, K., Shaw, J. G., Lomonossoff, G. P., Qiu, S. G., Linstead, P., Shanks, M., and Risco, C. 1997. The coat and cylindrical inclusion proteins of a potyvirus are associated with connections between plant cells. Virology 236:296-306.

Rusholme, R. L., Sharpe, A. G., Jenner, C. E., Hughes, S. L., Parkin, I. A., Walsh, J. A., and Lydiate, D. J. 1999. The genetics of resistance to turnip mosaic virus in Brassica. (Abstr.) Phytopathology 89(suppl.):S67.

Sánchez, F., Martínez-Herrera, D., Aguilar, I., and Ponz, F. 1998. Infectivity of turnip mosaic potyvirus cDNA clones and transcripts on the systemic host Arabidopsis thaliana and local lesion hosts. Virus Res. 55:207-219.

Santa Cruz, S., and Baulcombe, D. C. 1993. Molecular analysis of potato virus $\mathrm{X}$ isolates in relation to the potato hypersensitivity gene $N x$. Mol. Plant-Microbe Interact. 6:707-714.

Schaad, M. C., Lellis, A. D., and Carrington, J. C. 1997. VPg of tobacco etch potyvirus is a host genotype-specific determinant for long-distance movement. J. Virol. 71:8624-8631.

Sharpe, A. G., Parkin, I. A. P., Keith, D. J., and Lydiate, D. J. 1995. Frequent nonreciprocal translocations in the amphidiploid genome of oilseed rape (Brassica napus). Genome 38:1112-1121.

Shattuck, V. I. 1992. The biology, epidemiology and control of turnip mosaic virus. Plant Breed. Rev. 14:199-238.

Shukla, D. D., Ward, C. W., and Brunt, A. A. 1994. The Potyviridae. CAB International, Wallingford, U.K.

Walsh, J. A. 1989. Genetic control of immunity to turnip mosaic virus in winter oilseed rape (Brassica napus ssp. oleifera) and the effect of foreign isolates of the virus. Ann. Appl. Biol. 115:89-99.

Walsh, J. A., Sharpe, A. G., Jenner, C. E., and Lydiate, D. J. 1999. Characterisation of resistance to turnip mosaic virus in oilseed rape (Brassica napus) and genetic mapping of TuRB01. Theor. Appl. Genet. 99:1149-1154.

Weber, H., and Pfitzner, A. J. P. 1998. Tm- $2^{2}$ resistance in tomato requires recognition of the carboxy terminus of the movement protein of tomato mosaic virus. Mol. Plant-Microbe Interact. 11:498-503. 